\title{
Synthesis, spectrometric characterization and trypanocidal activity of some 1,3,4-thiadiazolines derivatives
}

\author{
Houssou Raymond FATONDJI ${ }^{1}$, Fernand GBAGUIDI ${ }^{2}$, Salomé KPOVIESSI ${ }^{1}$, Joanne \\ BERO $^{3}$, Gabrielle CHATAIGNE ${ }^{3}$, Véronique HANNAERT ${ }^{4}$, Joëlle QUETIN- \\ LECLERCQ $^{3}$, Jacques POUPAERT ${ }^{3}$ and Georges Coffi ACCROMBESSI ${ }^{1 *}$ \\ ${ }^{1}$ Laboratoire de Chimie Organique Physique et de Synthèse, Université d'Abomey-Calavi, Faculté des \\ Sciences et Techniques, BP 4521 Cotonou, Bénin. \\ ${ }^{2}$ Laboratoire National de Pharmacognosie/Centre Béninois de la Recherche Scientifique et Technique \\ (CBRST). BP 06 Oganla Porto-Novo, Bénin. \\ ${ }^{3}$ Louvain Drug Research Institute (LDRI) 73.40 B-1200 Brussels-Belgium, 73.30 B-1200 Brussels-Belgium. \\ ${ }^{4}$ Institut de Pathologie Cellulaire Christian Duve (ICP) 73.30 B-1200 Brussels-Belgium. \\ *Corresponding author, E-mail: coffiaccrombessi@yahoo.fr
}

\begin{abstract}
Six 1,3,4-thiadiazolines derivatives were synthesized by cyclization of thiosemicarbazones under acetylating condition with yields going from 27 to $94 \%$. The products purity was confirmed by LC/MS (Mass Spectrometry Coupled with High-Performance Liquid Chromatography) and they were characterized using spectrometry IR, NMR ${ }^{1} \mathrm{H}$ and ${ }^{13} \mathrm{C}$ (Nuclear Magnetic Resonance). These compounds were then tested in vitro on Trypanosoma brucei brucei according to the "LILIT, Alamar Blue" method to estimate their trypanocidal activity. 1,3,4-thiadiazoline $\mathbf{6}\left(\mathrm{IC}_{50}=38,79 \mu \mathrm{M}\right.$ ) was the most active of all compounds.
\end{abstract}

(C) 2010 International Formulae Group. All rights reserved.

Keywords: Cyclization, thiosemicarbazones, LC/MS, NMR, IR, Trypanosoma brucei brucei.

\section{INTRODUCTION}

African trypanosomes are parasitic protozoa that affect both man and animals. Trypanosoma brucei brucei is one of the causative agents of "Nagana" which decimate cattle. Trypanosoma brucei gambiense and Trypanosoma brucei rhodesiense are responsible for the African human trypanosomiase, an endemic disease in subSaharan Africa with nearly 50.000 estimated cases and a population at risk of 60 million people (WHO, 2007a). The toxicity and adverse effects of drugs that have been commonly used to treat this disease, their impractical dosing regimens (WHO, 2007b) as well as the damage caused in the sector of the breeding require the development of new active molecules in a most safe chemotherapeutic approach. Accordingly, our interest have been focused on 1,3,4thiadiazolines and 1,3,4-thiadiazoles which showed during the 50 last years a broad spectrum of pharmacological properties. 
Indeed, these small molecules exhibit various biological activities such as antituberculosis (Shucla et al.,1984; Foroumadi et al., 2002), antiviral (García et al., 2003), anticonvulsant (Chapleo et al., 1988), Fungicidal (Hagiwara et al., 1992), antihypertensive (Mazzone et al., 1993), hypoglycemic (Hanna et al., 1993), antimicrobial (Mamolo et al., 1996) antiinflammatory (Labanauskas et al., 2001), adenosine A3 receptor antagonists (Jung et al., 2004) and anticancer activities (Chou et al., 2003; Nakai et al., 2009). Finally, 1,3,4Thiadiazole and related compounds are of great interest in chemistry owing to their bioactivity on certain plant growth regulating effects as well as antimicrobial activity (Sancak et al., 2007).

However, the literature does not set great store by the trypanocidal activity of 1,3,4-thiadiazolines. The aim of this work is to synthesize some 1,3,4-thiadiazolines and to estimate their trypanocidal activities.

\section{MATERIALS AND METHODES Chemistry Apparatus}

We used thin layer chromatography (TLC) to estimate the compounds purity, to follow the evolution of the reactional medium of 1,3,4-thiadiazolines, and then to achieve their purification on silica gel column. The solvent used is the mixture of dichloromethane/ethyl acetate (2/1) or dichloromethane/methanol (9/1). Compounds purity was confirmed by LC/MS. The melting points were taken on a fusionometer eletrothermal 1A 9000. The spectrometric data were recorded with the following instruments: IR, Perkin Elmer FTIR 286; H NMR 1 and 13 NMR, Bruker 400; LC/MS in APCI mode on a C18 column. 1,3,4-thiadiazolines are synthesized as follows:

\section{Synthesis of 1,3,4-thiadiazolines}

A mixture of ketone $(20 \mathrm{mmol}$ dissolved in $100 \mathrm{ml}$ of ethanol) and thiosemicarbazide $(20 \mathrm{mmol}$ dissolved in 20 $\mathrm{ml}$ of $1 \mathrm{~N}$ hydrochloric acid) is stirred until the thiosemicarbazone precipitates. The precipitate is filtered, washed, dried and then recrystallized in ethanol $\left(96{ }^{\circ} \mathrm{C}\right)$ to give purified thiosemicarbazone crystals.

This thiosemicarbazone $(0.25 \mathrm{mmol})$ was dissolved in $0.5 \mathrm{~mL}$ of pyridine and 0.5 $\mathrm{mL}$ of acetic anhydride and the mixture was heated at $110{ }^{\circ} \mathrm{C}$ during $3 \mathrm{~h}$ with magnetic stirring to give the 1,3,4- thiadiazoline derivative (Brousse et al., 2002) which is filtered and purified by flash chromatography (Figure 1).

\section{Antitrypanosomal activity (LILIT, Alamar Blue ${ }^{\mathrm{TM}}$ )}

The test is performed on the bloodstream form of the strain 427 of Trypanosoma brucei brucei by the "Lilit Alamar Blue" method (Baltz et al., 1985; Räz et al., 1997). The stock solutions of 1,3,4-thiadiazolines have been prepared from an initial concentration of $10 \mathrm{mg} / \mathrm{ml}$ in DMSO. The trypanosomes are grown in a medium containing $10 \%$ of heat-inactivated fetal calf serum and bloodstream form supporting factor. The trypanosome suspensions were adjusted to $5.10^{-4}$ tryp/mL. In each well, $50 \mu$ l of different dilutions of the stock solution were added to $50 \mu \mathrm{l}$ of suspension of trypanosomes. The plates were then incubated at $37^{\circ} \mathrm{C}$ for 72 hours in an atmosphere with $5 \% \mathrm{CO}_{2} .10 \mu \mathrm{l}$ of dye "Alamar Blue ${ }^{\mathrm{TM}}$ " is added to each well and then incubated for 4 hours.

The dye "Alamar Blue ${ }^{\text {TM" }}$ is a reagent for detecting enzymatic activity. The wells in which the concentration of compound is insufficient to inhibit the proliferation of trypanosomes are stained. The CMI is the concentration of unstained wells in which there is the lowest amount of 1,3,4thiadiazole. The plate reading is made in comparison with control wells on a fluorescence plate reader using an excitation wavelength of $530 \mathrm{~nm}$ and an emission wavelength $590 \mathrm{~nm}$.

\section{Statistical analysis}

Lethality assays were evaluated by Excel computer statistical program to determine the $\mathrm{LC}_{50}$. Values are means of 
two experiments; standard deviation $( \pm \mathrm{sd})$ is given in parentheses (Table 1).

\section{RESULTS}

Chemistry

Six 1,3,4-thiadiazolines were synthesized with yields going from 27 to $94 \%$. The physical and spectrometric data of these compounds are reported below.

\section{5-Acetamido-3- $N$-acetyl-2-methyl-2- phenyl-1,3,4-thiadiazoline (1)}

Yield: $57 \%$. M.p : 224-225 ${ }^{\circ} \mathrm{C}$. Rf $\mathrm{CH}_{2} \mathrm{Cl} 2 / \mathrm{MeOH} \quad(9 / 1): 0.53: \quad \mathrm{MS}: \quad[\mathrm{MH}]^{+} \mathrm{cal}$ 278,09564 [MH $]^{+}$found 278.09577 IR data $\left(\mathrm{KBr} \mathrm{cm}{ }^{-1}\right): 3145 v(\mathrm{NH}), 1694,1631,1615$ $v(\mathrm{C}=\mathrm{O}$ amide $) .{ }^{1} \mathrm{H}$ NMR data $\left(\mathrm{CDCl}_{3} \delta \mathrm{ppm}\right)$ : $1.84\left(3 \mathrm{H}, \mathrm{s}, \mathrm{CH}_{3}\right) ; 2.22$ (3H, s, $\mathrm{CH}_{3}$ amide); $2.29\left(3 \mathrm{H}, \mathrm{s}, \mathrm{CH}_{3}\right.$ amide $) ; 7.15-7.35(5 \mathrm{H}$, several signals, $\mathrm{ArH}) ; 9.14(1 \mathrm{H}, \mathrm{s}, \mathrm{NH}) .{ }^{13} \mathrm{C}$ NMR data $\left(\mathrm{CDCl}_{3} \delta \mathrm{ppm}\right): 22.87\left(\mathrm{CH}_{3}\right)$; 25.89 and $26.86\left(\mathrm{CH}_{3}\right.$ amide $) ; 80.03\left(\mathrm{C}_{2}\right.$ in the ring); 124.99-142.82 (aromatic C); 143.48 $(\mathrm{C}=\mathrm{N}) ; 168.84$ and $169.27(\mathrm{C}=\mathrm{O}$ amide $)$.

\section{5-Acetamido-3- $N$-acetyl-2-(2' -} chlorophenyl)-2-methyl-1,3,4-thiadiazoline (2)

Yield: $27 \%$. M.p : $215-217{ }^{\circ} \mathrm{C} . \quad \mathrm{Rf}$ CH2Cl2/AcOET (2/1): 0.58 MS: $[\mathrm{MH}]^{+}$cal 312.0568 $[\mathrm{MH}]^{+}$found 312.0565 . IR data $\left.(\mathrm{KBr} \mathrm{cm})^{-1}\right)$ : $3160 v(\mathrm{NH}), \quad 1698, \quad 1644,1611 v(\mathrm{C}=\mathrm{O}$ amide). ${ }^{1} \mathrm{H}$ NMR data $\left(\mathrm{CDCl}_{3} \delta \mathrm{ppm}\right): 1.86$ $\left(3 \mathrm{H}, \mathrm{s}, \mathrm{CH}_{3}\right) ; 2.26\left(3 \mathrm{H}, \mathrm{s}, \mathrm{CH}_{3}\right.$ amide); 2.36 (3H, s, $\mathrm{CH}_{3}$ amide); 7.19-7.42 (4H, several signals, ArH); 9.61 (1H, s, NH). ${ }^{13} \mathrm{C}$ NMR data $\left(\mathrm{CDCl}_{3} \delta \mathrm{ppm}\right): 22.96\left(\mathrm{CH}_{3}\right.$ amide $)$; $23.01\left(\mathrm{CH}_{3}\right.$ amide $) ; 28.85\left(\mathrm{CH}_{3}\right) ; 78.35\left(\mathrm{C}_{2}\right.$ in the ring); 126.64-137.27 (aromatic C); 144,37 $(\mathrm{C}=\mathrm{N}) ; 168.68$ and $168.78(\mathrm{C}=\mathrm{O}$ amide $)$.

\section{5-Acetamido-3- $\mathrm{N}$-acetyl-2-(4'-} chlorophenyl)-2-methyl-1,3,4-thiadiazoline (3)

Yield: 58\%. M.p : 214-216 ${ }^{\circ} \mathrm{C} . \quad \mathrm{Rf}$ CH2Cl2/AcOET (2/1): 0.61 MS: $[\mathrm{MH}]^{+}$cal 312.0568 $[\mathrm{MH}]^{+}$found 312.0567 . IR data $\left.(\mathrm{KBr} \mathrm{cm})^{-1}\right)$ : $3146 v(\mathrm{NH}), \quad 1694, \quad 1633,1617 \quad v(\mathrm{C}=\mathrm{O}$ amide). ${ }^{1} \mathrm{H} \mathrm{NMR}$ data $\left(\mathrm{CDCl}_{3} \delta \mathrm{ppm}\right): 1.75$ $\left(3 \mathrm{H}, \mathrm{s}, \mathrm{CH}_{3}\right) ; 2.22\left(3 \mathrm{H}, \mathrm{s}, \mathrm{CH}_{3}\right.$ amide); 2.24 (3H, s, $\mathrm{CH}_{3}$ amide); 7.19-7.27 $(4 \mathrm{H}$, several signals, ArH); $10.14(1 \mathrm{H}, \mathrm{s}$, $\mathrm{NH}) .{ }^{13} \mathrm{C}$ NMR. data $\left(\mathrm{CDCl}_{3} \delta \mathrm{ppm}\right): 22.49$ $\left(\mathrm{CH}_{3}\right) ; 23.78\left(\mathrm{CH}_{3}\right.$ amide $) ; 26.62\left(\mathrm{CH}_{3}\right.$ amide); $78.90\left(\mathrm{C}_{2}\right.$ in the ring); 126.68141.31 (aromatic $\mathrm{C}) ; 144.86(\mathrm{C}=\mathrm{N}) ; 169.40$ and $169.56(\mathrm{C}=\mathrm{O}$ amide $)$.

\section{5-Acetamido-3- $N$-acetyl-2-(3'- bromophenyl)-2-methyl-1,3,4- thiadiazoline (4)}

Yield: $76 \%$. M.p : $238-239{ }^{\circ} \mathrm{C}$. Rf CH2Cl2/AcOET $\quad(2 / 1): 0.57$ MS: $[\mathrm{MH}]^{+}$cal 358.0048 $[\mathrm{MH}]^{+}$found 358.0046. IR data $\left(\mathrm{KBr} \mathrm{cm}^{-1}\right): 3148 \quad v(\mathrm{NH}), \quad 1695,1614$ $v\left(\mathrm{C}=\mathrm{O}\right.$ amide). ${ }^{1} \mathrm{H}$ NMR (DMSO $\left.\delta \mathrm{ppm}\right)$ : $2.03\left(3 \mathrm{H}, \mathrm{s}, \mathrm{CH}_{3}\right) ; 2.20$ (3H, s, $\mathrm{CH}_{3}$ amide); 2.27 (3H, s, $\mathrm{CH}_{3}$ amide); 7.26-7.52 (4H, several signals, ArH); 11.69 (1H, s, NH). ${ }^{13} \mathrm{C}$ NMR data (DMSO $\delta \mathrm{ppm}$ ): 22.40 $\left(\mathrm{CH}_{3}\right) ; 23.58\left(\mathrm{CH}_{3}\right.$ amide $) ; 26.30\left(\mathrm{CH}_{3}\right.$ amide); $77.86\left(\mathrm{C}_{2}\right.$ in the ring); 121.72142.30 (aromatic C); $144.36(\mathrm{C}=\mathrm{N}) ; 167.77$ and 169.45 ( $\mathrm{C}=\mathrm{O}$ amide $)$.

\section{5-Acetamido-3- $N$-acetyl-2-(4'- bromophenyl)-2-methyl-1,3,4- thiadiazoline (5)}

Yield: 78\%. M.p : 211-213 ${ }^{\circ}$ C. Rf CH2C12/AcOET $(2 / 1): 0.67$ MS: $[\mathrm{MH}]^{+}$cal $358.0048[\mathrm{MH}]^{+}$found 358.0038 . IR data $\left(\mathrm{KBr} \mathrm{cm}^{-1}\right): 3218,3148 v(\mathrm{NH}), 1693,1614$ $v(\mathrm{C}=\mathrm{O}$ amide $) .{ }^{1} \mathrm{H}$ NMR data $\left(\mathrm{CDCl}_{3} \delta\right.$ ppm): $1.75\left(3 \mathrm{H}, \mathrm{s}, \mathrm{CH}_{3}\right) ; 2.22\left(3 \mathrm{H}, \mathrm{s}, \mathrm{CH}_{3}\right.$ amide); 2.24 (3H, s, $\mathrm{CH}_{3}$ amide);7.19-7.24 $(4 \mathrm{H}$, several signals, ArH $) ; 10.32(1 \mathrm{H}, \mathrm{s}$, $\mathrm{NH}) .{ }^{13} \mathrm{C} \mathrm{NMR}$ data $\left(\mathrm{CDCl}_{3} \delta \mathrm{ppm}\right): 22.54$ $\left(\mathrm{CH}_{3}\right) ; 23.85\left(\mathrm{CH}_{3}\right.$ amide $) ; 26.59\left(\mathrm{CH}_{3}\right.$ amide); $78.85\left(\mathrm{C}_{2}\right.$ in the ring); 121.93141.85 (aromatic C); $144.34(\mathrm{C}=\mathrm{N}) ; 169.39$ and $169.55(\mathrm{C}=\mathrm{O}$ amide $)$.

\section{5-Acetamido-3- $N$-acetyl-2-(2'- nitrophenyl)-1,3,4-thiadiazoline (6)}

Yield: $94 \%$. M.p : 245-246 ${ }^{\circ} \mathrm{C}$. Rf CH2Cl2/AcOET $\quad(2 / 1): 0.37$ MS: $[\mathrm{MH}]^{+} \mathrm{cal}$ $308.3130[\mathrm{MH}]^{+}$found 308.3132 . IR data $\left(\mathrm{KBr} \mathrm{cm}^{-1}\right): 3232,3192 v(\mathrm{NH}), 1682,1664$ $v\left(\mathrm{C}=\mathrm{O}\right.$ amide). ${ }^{1} \mathrm{H}$ NMR data (DMSO $\delta$ ppm): 2.04 (3H, s, $\mathrm{CH}_{3}$ amide); 2.26 (3H, s, 
5-Acetamido-3- $N$-acetyl-2-(2'nitrophenyl)-1,3,4-thiadiazoline (6)

Yield: 94\%. M.p : $245-246{ }^{\circ} \mathrm{C} . \quad \mathrm{Rf}$ CH2C12/ACOET (2/1): $0.37 \mathrm{MS}:[\mathrm{MH}]^{+}$cal 308.3130 $[\mathrm{MH}]^{+}$found 308.3132 . IR data $\left(\mathrm{KBr} \mathrm{cm}^{-1}\right)$ : $3232, \quad 3192 v(\mathrm{NH}), \quad 1682,1664 v(\mathrm{C}=\mathrm{O}$ amide). ${ }^{1} \mathrm{H}$ NMR data (DMSO $\delta$ ppm): 2.04 ( $3 \mathrm{H}, \mathrm{s}, \mathrm{CH}_{3}$ amide); 2.26 (3H, s, $\mathrm{CH}_{3}$ amide); $5.51\left(1 \mathrm{H}, \mathrm{s}, \mathrm{C}_{2}\right.$ in the ring); 7.26-8.18 $(4 \mathrm{H}$, several signals, $\mathrm{ArH}) ; 11.86(1 \mathrm{H}, \mathrm{s}, \mathrm{NH}) .{ }^{13} \mathrm{C}$ NMR data (DMSO $\delta \mathrm{ppm}): 21.70\left(\mathrm{CH}_{3}\right)$; 22.41 (CH3 amide); $63.15\left(\mathrm{C}_{2}\right.$ in the ring); 125.52-145.83 (aromatic C); $146.31(\mathrm{C}=\mathrm{N})$ and 169.66 ( $\mathrm{C}=\mathrm{O}$ amide).

IR spectra of 1,3,4-thiadiazolines show bands in the area of $3232-3145 \mathrm{~cm}-1$ due to the stretching vibration of $\mathrm{NH}$. In ${ }^{1} \mathrm{H}$ NMR, the most deshielded proton, which is linked to the central nitrogen atom, appears as a broadened singlet between 8.9 and 11.69 ppm. Ring closure in 1,3,4-thiadiazolines may be observed by: 1) the disappearance of the signal between 176 and 180 corresponding to the thiocarbonyl; 2) the appearance of a signal between 77 and 81 ppm assigned to $\mathrm{C}-2$; and 3 ) the signals of the carbonyl and methyl moieties of the acetyl groups incorporated to the molecule.
In mass spectrometry, the $[\mathrm{MH}]^{+}$ peaks obtained in APCI mode correspond to molecular weights expected for all products. In LC mode, all 1,3,4thiadiazoles have a single peak confirming their purity.

\section{Trypanocidal activity}

The synthesized compounds were tested for their trypanocidal activity on Trypanosoma brucei brucei. The test results are reported in Table 1.

The data of this table indicate that compounds 1 and 4 have $\mathrm{LC}_{50}$ values well above $100 \mu \mathrm{M}$.

The thiadiazoline 2, 3 and 5 have respective $\mathrm{LC}_{50}$ values of $172.76,175.93$ and $134.70 \mu \mathrm{M} . \mathrm{LC}_{50}$ values are greater than $100 \mu \mathrm{M}$ for thiadiazoline 1-5 which have halogen substituents $(\mathrm{Cl}$ or $\mathrm{Br})$ on the benzene ring. These compounds have a little trypanocidal activity. The thiadiazoline 6 which have a nitro group in ortho position on the benzene ring appears as a moderate trypanocidal with a $\mathrm{LC}_{50}$ value of $38.79 \mu \mathrm{M}$.

Table 1: Structure and trypanocidal activity of 1,3,4-thiadiazolines.

\begin{tabular}{lccc}
\hline Compounds & $\mathbf{R}$ & $\mathbf{I C}_{\mathbf{5 0}}$ - $\mathbf{m o y} \pm \mathbf{s d}(\boldsymbol{\mu g} \mathbf{/ m l})$ & $\mathbf{I C}_{\mathbf{5 0}}$ - $\mathbf{m o y} \pm \mathbf{s d}(\boldsymbol{\mu M})$ \\
\hline 1 & - & $>100$ & - \\
2 & $2^{\prime}-\mathrm{Cl}$ & $53,73 \pm 3,1$ & $172,76 \pm 8,44$ \\
3 & $4^{\prime}-\mathrm{Cl}$ & $54,72 \pm 0,6$ & $175,93 \pm 1,83$ \\
4 & $3^{\prime}-\mathrm{Br}$ & $>100$ & - \\
5 & $4^{\prime}-\mathrm{Br}$ & $47,96 \pm 4,94$ & $134,7 \pm 16,63$ \\
6 & - & $11,96 \pm 4,26$ & $38,79 \pm 13,81$ \\
\hline
\end{tabular}

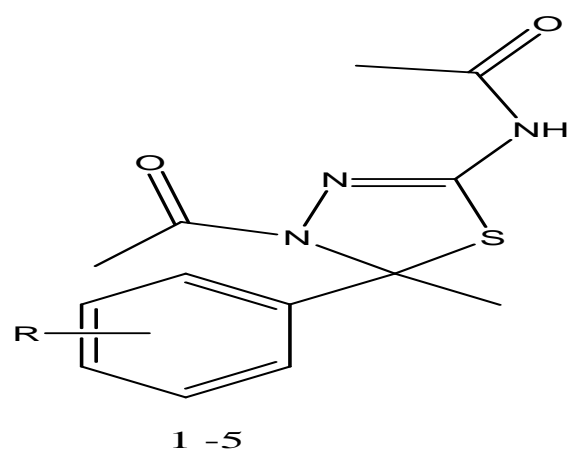




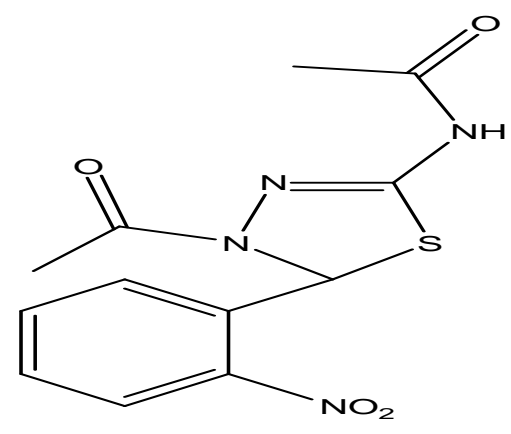

6

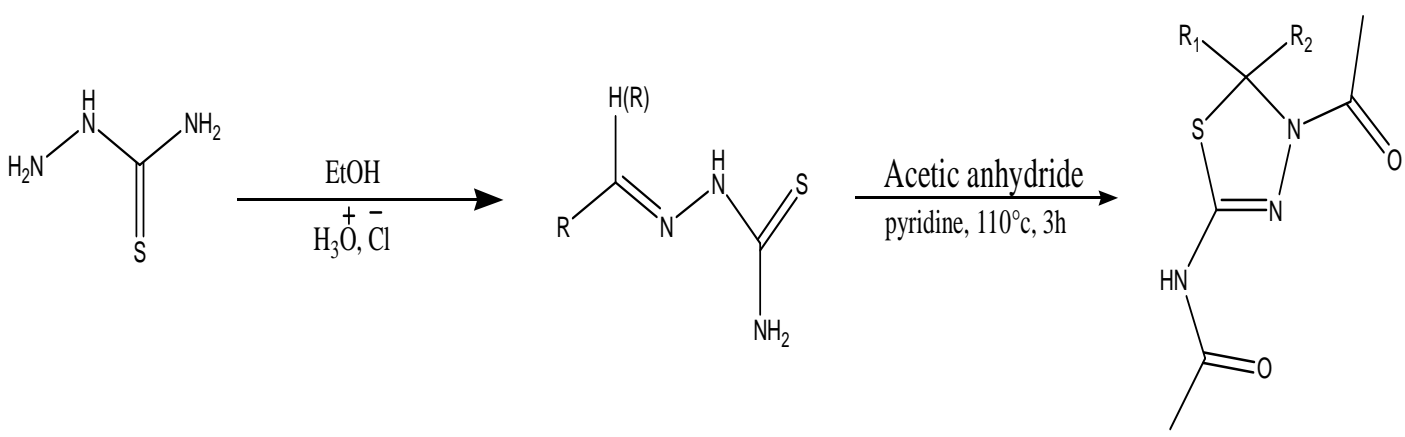

Figure 1: Synthesis of 1,3,4-thiadiazolines.

\section{DISCUSSION}

The spectrometric data of the six synthesized compounds are in conformity with the structures suggested for the products: 5-Acetamido-3- $N$-acetyl-2-methyl-2-phenyl1,3,4-thiadiazoline (1); 5-Acetamido-3- $N$ acetyl-2-(2'-chlorophenyl)-2-methyl-1,3,4thiadiazoline (2); 5-Acetamido-3- $N$-acetyl-2(4'-chlorophenyl)-2-methyl-1,3,4-

thiadiazoline (3); 5-Acetamido-3- $N$-acetyl-2(3'-bromophenyl)-2-methyl-1,3,4-

thiadiazoline (4); 5-Acetamido-3- $\mathrm{N}$-acetyl-2(4'-bromophenyl)-2-methyl-1,3,4-

thiadiazoline (5); 5-Acetamido-3- $\mathrm{N}$-acetyl-2(2'-nitrophenyl)-1,3,4-thiadiazoline (6).

Thiosemicarbazones are known to inhibit cysteine proteases such as cathepsins : Tbcat $B$ and rhodesain. It has been suggested that these proteases may be involved in nutrient acquisition, degradation of host proteins, evasion of the host immune response, or crossing of the blood brain barrier and are essential for the parasite survival (Caffrey et al., 2001; Hirumi et al., 1994). Inhibition of these proteases by thiosemicarbazones has been demonstrated and would consequently result in the death of the parasite Trypanosoma brucei brucei (Caffrey et al., 2001; Hirumi et al., 1994). 1,3,4-thiadiazolines which are cyclic deravatives of thiosemicarbazones could have the same action mechanism on Trypanosoma brucei brucei. The literature does not set great store by the trypanocidal activity of 1,3,4thiadiazolines. Then, cyclized products were purified by flash chromatography and their purity confirmed by LC/MS to highlight the specific trypanocidal activity of 1,3,4thiadiazolines. This cyclized compounds showed trypanocidal activity. Thus, $\mathrm{IC}_{50}$ value of compound $6(38.79 \mu \mathrm{M})$ indicates that this compound is the most active. The other 1,3,4thiadiazolines have $\mathrm{IC}_{50}$ value higher than 100 $\mu \mathrm{M}$. According to the work of $\mathrm{Du}$ et al. (2002) and Fujii et al. (2005), thiosemicarbazones are trypanocidal when their $\mathrm{IC}_{50}$ values are less than $10 \mu \mathrm{M}$, moderate trypanocidal if these values are between 10 and $100 \mu \mathrm{M}$, and have little or no 
activity when their $\mathrm{IC}_{50}$ are higher than 100 $\mu \mathrm{M}$.

\section{Conclusion}

In order to estimate their trypanocidal activity, six 1,3,4-thiadiazolines :

5-Acetamido-3- $N$-acetyl-2-methyl-2-phenyl1,3,4-thiadiazoline (1); 5-Acetamido-3- $N$ acetyl-2-(2'-chlorophenyl)-2-methyl-1,3,4thiadiazoline (2); 5-Acetamido-3- $\mathrm{N}$-acetyl-2(4'-chlorophenyl)-2-methyl-1,3,4-

thiadiazoline (3); 5-Acetamido-3- $\mathrm{N}$-acetyl-2(3'-bromophenyl)-2-methyl-1,3,4-

thiadiazoline (4); 5-Acetamido-3- $N$-acetyl-2(4'-bromophenyl)-2-methyl-1,3,4-

thiadiazoline (5) and 5-Acetamido-3- $N$ acetyl-2-(2'-nitrophenyl)-1,3,4-thiadiazoline

(6) were synthesized and purified by flash chromatography. Their purity was confirmed by LC/MS and their structures were completely determined by spectrometric analysis. All compounds were tested on Trypanosoma brucei brucei. The 1,3,4thiadiazoline (6) was found more active than the other compounds. This first study lead us to conclude that 1,3,4-thiadiazolines may have trypanocidal activity.

\section{ACKNOWLEDGEMENTS}

Financial and technical support of this work by the Belgium Kingdom through GDCD (General Direction for Development Cooperation) and BTC (Belgian Technical Cooperation) is highly appreciated.

\section{REFERENCES}

Baltz T, Baltz D, Giroud C, Crockett J. 1985. Cultivation in a semi defined medium of animal infective forms of Trypanosoma brucei, T. equiperdum, T. evansi, T. rhodhesiense et T.gambiense. The EMBO Journal, 4(5): 1273-1277.

Brousse BN, Moglioni AG, Alho MM, Álvarez-Larena A, Moltrasio GY, D'Accorso NB. 2002. Behavior of thiosemicarbazones derived from some terpenones under acetylating conditions. ARKIVOC, 10: 14-23.
Caffrey CR, Hansell E, Lucas KD, Brinen LS, Cheng J, Gwaltney SL, Roush WR, Stierhof YD, Bogyo M, Steverding D, McKerrow JH. 2001. Active site mapping, biochemical properties et subcellular localization of rhodesain, the major cysteine protease of Trypanosoma brucei rhodesiense. Mol. Biochem. Parasitol., 118: 61-73.

Chapleo CB, Myers PL, Smith ACB, Stillings MR, Tulloch IF, Walter SD. 1988. Substituted 1'3'4-thiadiazolines with anticonvulsant activity. 4. Amidines. $J$. Med. Chem., 31: 7-11.

Chou JY, Lai SY, Pan SL, Chern JW, Guh JH. 2003. Investigation of anticancer mechanism of thiadiazole-based compound in human non-small cell lung cancer A549 cells. Biochem Pharmacol., 66: 115-124.

Du X, Cuo C, Hansell E, Doyle PS, Caffrey CR, Holler TP, McKerrow JH, Cohen FE. 2002. Synthesis and structure-Activity Relationship Study of Potent Trypanocidal Thiosemicarbazones Inhibitions of the Trypanosomal Cysteine Protease Cruzain, J. Med. Chem., 45: 2695-2707.

Foroumadi A, Asadipour A, Mirzaei M, Karimi J, Emami S. 2002. Antituberculosis agents. V. Synthesis, evaluation of in vitro antituberculosis activity and cytotoxicity of some 2-(5nitro-2-furyl)-1,3,4-Thiadiazoles derivatives. II Farmaco., 57: 765-769.

Fujii N, Mallari JP, Hansell EJ, Mackey Z, Doyle P, Zhou YM, Gut J, Rosenthal PJ, McKerrow JH, Guy RK. 2005. Discovery of potent thiosemicarbazone inhibitors of rhodesain and cruzain. Bioorganic \& Medicinal Chemistry Letters, 15(1): 121123.

García CC, Brousse BN, Carlucci MJ, Moglioni AG, Alho MM, Moltrasio GY, D'arccorso NB, Damonte EB. 2003. Inhibitory effect of thiosemicarbazone derivatives on Junin virus replication in vitro. Antiviral Chemistry and Chemotherapy, 14: 99-105. 
Hagiwara K, Hashimoto S, Shimoda S. 1992. Synthesis and fungicidal activity of 1,2,4thiadiazolines. J. Pesticide Sci., 17: 251259.

Hanna MA, Girges MM, Rasala D, Gawinecki R. 1993. Synthesis et pharmacological evaluation of some novel 5-(pyrazol-3yl)thiadiazole et oxadiazole derivatives as potential hypoglycemic agents. ArzneimForsch./ Drug Res., 45 :1074-1078.

Hirumi H, Hirumi K. 1994. Axenic culture et African Trypanosome bloodstream forms. Parasitology Today, 10(2): 80-84.

Jung KY, Kim SK, Gao ZG, Gross AS, Melman N, Jacobson, KA, Kim YC. 2004. Structure activity relationships of thiazole and thiadiazole derivatives as potent and selective human adenosine A3 receptor antagonists. Bioorg. Med. Chem., 12: 613-623.

Labanauskas L, Kalcas V, Udrenaite E, Gaidelis P, Brukstus A, Dauksas V. 2001. Synthesis of 3-(3,4-dimethoxyphenyl)-1 $\mathrm{H}$-1,2,4-triazole-5-thiol et 2-amino-5(3,4-dimethoxyphenyl)-1,3,4-thiadiazole derivatives exhibiting anti-inflammatory activity. Pharmazie., 56: 617-619.

Mamolo MG, Vio L, Banfi E. 1996. Synthesis and antimycobacterial activity of some indole derivatives of pyridine-2carboxamidrazone et quinoline-2carboxamidrazone. Farmaco., 51: 71-74.
Mazzone G, Pignatello R, Mazzone S, Panico A, Pennisi G, Castana R, Mazzone P. 1993. Synthesis et local anesthetic activity of alkylaminoacyl derivatives of 2-amino-1,3,4-thiadiazole. Farmaco., 48: 1207-1224.

Räz B, Iten M, Grether-Bühler Y, Kaminsky R, Brun R. 1997. The Alamar Blue ${ }^{R}$ essay to determine drugs sensitivity of African trypanosomes (T. b. rhodhesiense and T. b. gambiense) in vitro. Acta Tropica., 68: 139-147.

Nakai R, Iida S, Takahash T, Tsujita T, Okamoto S, Takada C, Akasaka K, Ichikawa S, Ishida H, Kusaka H, Akinaga S Murakata C, Honda S, Masayuki Nitta M, Saya H, Yamashita Y. 2009. K858, a Novel inhibitor of mitotic kinesin Eg5 and antitumor agent, induces cell death in cancer cells. Cancer Res., 69(9): 39013909.

Sancak K, Unver Y, Er M. 2007. Synthesis of 2-acylamino, 2-aroylamino et ethoxycarbonyl imino-1'3'4thiadiazolines as antitumor agents. Turk J. Chem., 31: 125-134.

Shucla HK, Desai NC, Astik RR. 1984. The uses of phenylthiosemecarbazide in heterocyclic syntheses. J. Indian Chem. Soc., 61: 168-175.

WHO. 2007a. Sleeping sickness. http://www.who.int/mediacentre/factsheet s/fs259/en/

WHO. 2007b. Sleeping sickness. Treatment schedule. World Health Organization. 